\title{
Pemilihan Supplier Obat yang tepat dengan Metode Simple Additive Weighting
}

\author{
Cyntia Trimulia ${ }^{1}$, Sarjon Defit ${ }^{2}$, Gunadi Widi Nurcahyo ${ }^{3}$ \\ 1,2,3 Jurusan Teknik Informatika, Fakultas Ilmu Komputer, Universitas Putra Indonesia YPTK Padang \\ Jl. Raya Lubuk Begalung, Kota Padang, 25221 \\ Email: cyntiatrimuli88@gmail.com, gunadiwidi@yahoo.co.id, sarjonde@yahoo.co.uk
}

\begin{abstract}
ABSTRAK
Apotek adalah perusahaan yang bergerak di bidang farmasi berupa obat-obatan. Obat-obatan bersumber dari beberapa supplier. Dengan banyaknya supplier menyebabkan sulit dalam menentukan supplier yang bagus. Untuk menentukan supplier yang baik, maka dibutuhkan sebuah sistem pengambilan keputusan. Metode yang digunakan untuk mengambil keputusan dalam penelitian ini adalah Simple Additive Weighting (SAW). Data yang diolah berupa data-data kualitas, harga, petunjuk kegunaan, garansi, pemesanan, pemenuhan pesanan, dan pelayanan. Penilaian dapat dikembangan dengan kriteria yang akan di jadikan acuan untuk perengkingan supplier yang ada. Penilaian dari masing-masing kriteria diperoleh dari penilaian pemilik Apotek Mama Jakarta itu sendiri. Dengan adanya pemilihan supplier nantinya akan memudahan untuk membandingkan hasil kinerja supplier. Hasil yang didapatkan dengan menggunakan metode ini mampu mendapatkan supplier terbaik. Pengambilan keputusan ini membantu pemilik apotek dalam melakukan evaluasi terhadap supplier.
\end{abstract}

Kata Kunci: Supplier, SPK, Simple Additive Weighting

\begin{abstract}
Pharmacy is a company engaged in the pharmaceutical sector in the form of medicines. Medicines are sourced from several suppliers. With many suppliers, it is difficult to determine good suppliers. To determine a good supplier, a decision-making system is needed. The method used to make decisions in this study is Simple Additive Weighting (SAW). Data processed is in the form of data on quality, price, instructions for use, warranty, ordering, order fulfillment, and service. Assessments can be developed with the criteria that will be used as a reference for the cracking of existing suppliers. The assessment of each criterion was obtained from the assessment of the owner of the Mama Jakarta Pharmacy itself. With supplier selection, it will be easier to compare supplier performance results. The results obtained using this method are able to get the best suppliers. This decision making helps pharmacy owners in evaluating suppliers.
\end{abstract}

Keywords: Supplier, DSS, Simple Additive Weighting

\author{
Corresponding Author: \\ Chyntia Trimulia \\ Jurusan Teknik Informatika, Fakultas Ilmu Komputer \\ Universitas Putra Indonesia YPTK Padang \\ Email: cyntiatrimuli88@gmail.com
}

\section{Pendahuluan}

Supplier pada apotek sangatlah penting, ketersediaan barang yang dibutuhkan harus terpenuhi agar aktivitas apotek berjalan dengan lancar [1], mendapatkan supplier yang menawarkan biaya yang bersaing dengan supplier lainnya dan memberikan kemudahan dalam pemesanannya [2], maka pihak apotek harus selektif dan cermat dalam memilih supplier dalam memasok barang.

Dengan menggunakan metode Simple Additive Weighting (SAW) akan digunakan untuk perhitungan pemilihan supplier terbaik, Simple Additive Weighting (SAW) adalah metode pencarian alternatif optimal dari sejumlah aternatif dengan kriterian tertentu [3], juga dikenal dengan sistem pembobotan [4]. Dalam proses perhitungan dengan menggunakan metode SAW yaitu tentukan kriteria yang akan digunakan dalam proses perengkingan supplier terbaik, mengevaluasi setiap alternatif dalam kriteria yang sudah ditentukan, buat matrik keputusan berdasarkan kriteria, hasil dari perkalian matrik dengan nilai tertinggi nantinya akan jadi hasil akhir yang dijadikan alternatif sebagai keputusan pemilihan supplier terbaik [5].

Tujuan utama dari proses pemilihan supplier adalah untuk menentukan supplier yang memiliki efisiensi dalam memenuhi kebutuhan apotek secara konsisten dan meminimasi resiko yang berkaitan dengan pengadaan obat-obatan maupun komponen yang dibutuhkan Apotek. Dengan metode SAW ini dapat 
membantu dalam melakukan penilaian agar tidak diukur sebatas pendapat dan perasaan saja. Pemilihan kriteria ditentukan oleh apotek sesuai dengan tingkat kebutuhan [2], dan penilaian dari masing-masing kriteria diperoleh dari penilaian pemilik Apotek Mama Jakarta. Penelitian ini nantinya akan membantu pemilik apotek dalam membandingkan kinerja masing-masing supplier yang bekerja sama dengan apotek.

Dari beberapa penelitian terdahulu dapat diterapkan pada berbagai bidang permasalahan, Promosi Kenaikan Jabatan Pada Sebuah Perusahaan [6] dari hasil analisis perhitungan dengan menggunakan metode Simple Additive Weighting dan dari hasil kuisioner penilaian karyawan yang terdiri dari kriteria masa kerja, penilaian kinerja, penilaian perilaku, karyawan bernama Chairani Syifa mendapatkan nilai sempurna dengan persentase $100 \%$. Sama halnya dengan penelitian sebelumnya Seleksi Penerimaan Calon Asisten Pratikum [7], hasil pengujian sistem pendukung keputusan untuk menentukan asisten praktikum di STMIK AMIKOM Yogyakarta, dengan menggunakan data testing diperoleh tingkat keakuratan sistem sebesar $90 \%$.

Peneliitan berikutnya Pemilihan Bantuan Bedah Rumah [8], sistem ini mampu mengambil keputusan secara akurat dan tidak membutuhkan waktu yang lama dalam pengambilan keputusan. Begitu juga dengan Penentuan Tunjangan Kinerja Pegawai Pada Kepolisisan Resort Kota Jambi [9], sistem pengolahan data pendukung keputusan ini dapat meminimalisir kesalahan dalam pemberian tunjangan kinerja sehingga pemberiannya diberikan berdasarkan hasil penilaian kinerja dan merupakan reward bagi pegawai yang telah bertugas dengan baik. Sistem ini dapat membantu pengambilan keputusan oleh Pimpinan (Kapolresta Jambi).

Selain metode Simple Additive Weighting (SAW) dalam menyelesaikan Sistem Pendukung Keputusan ada beberapa metode lain, Penerimaan Pegawai dengan Metode TOPSIS [10], ini dapat diimplementasikan dengan mudah, serta dapat membantu dalam memberikan rekomendasi pelamar terbaik sesuai dengan kriteria yang ditentukan pada proses penerimaan pegawai di Rumah Sakit Akademik UGM. Penelitian selanjutnya Pemilihan Supplier Bahan Baku Oli Bs150 [11] menggunakan Analytical Hierarchy Process (AHP) dari ketiga kriteria yang sudah ditentukan oleh perusahaan yaitu kualitas, fleksibilitas dan biaya maka kriteria yang memiliki bobot paling tinggi dan menjadi prioritas pertama dalam pemilihan supplier bahan baku oli BS150 adalah kualitas dengan bobot 0,620 atau $62 \%$ dikarenakan kualitas bahan baku oli BS150 terbagi menjadi dari tiga kualitas yang tersedia di pasaran sehingga perusahaan harus bisa mendapatkan kualitas bahan baku yang terbaik untuk dapat menghasilkan hasil produksi yang dapat bersaing di pasaran, dan penelitian berikutnya dengan metode yang sama metode Analytical Hierarchy Process (AHP) Pemilihan Mahasiswa Berprestasi di STMIK Atma Luhur Pangkalpinang [12], dengan menggunakan hasil pengolahan data dengan Expert Choice menunjukkan bahwa kriteria yang paling penting secara berturut-turut menurut responden ahli adalah karya tulis 19,5\%, IPK 17,3\%, kegiatan mahasiswa $17,2 \%$ dan kepribadian 16,5\%, ekstrakulikuler $15,0 \%$, bahasa inggris $14,4 \%$. Sedangkan alternatif yang paling penting secara berturut-turut menurut responden ahli adalah Mahasiswa A 37,9\%, Mahasiswa B 33,9\% dan Mahasiswa C 28,2\%, dan penelitian terakhir Sistem Transportasi Umum [13], menggunakan metode Informasi Geografis, Sistem Pendukung Keputusan dalam transit perkotaan mampu menghasilkan beberapa jalur alternatif berdasarkan jejak masyarakat setempat layanan transportasi dan dari sumber dan tujuan yang diberikan oleh pengguna telah diterapkan. Aplikasi ini akan meningkatkan lokasi tampilan kendaraan di halte bus untuk non-seluler, pengguna dan juga mengidentifikasi informasi lebih lanjut tentang kendaraan dan pengemudi kepada pengguna yang yang membatu masyarakat untuk menghindari kemacetan.

Masalah permasalahan yang ditemukan:

a. Bagaimana penerapan metode Simple Additive Weighting (SAW) dapat membantu dalam pengambilan keputusan yang optimal untuk pemilihan supplier?

b. Bagaimana mengimplementasikan Sistem Pendukung Keputusan dalam penilaian supplier terbaik berdasarkan kriteria yang ditentukan?

\section{Metode Penelitian}

\section{Simple Additive Weighting (SAW)}

Metode SAW sering juga dikenal istilah metode penjumlahan terbobot. Konsep dasar metode SAW yaitu mencari penjumlahan terbobot dari rating kinerja pada setiap alternatif dari semua atribut. Dalam proses penyelesaian SAW terlebih dahulu menentukan masalah yang dipecahkan dengan menggunakan kriteria 1, kriteria 2 sampai ke kriteria n, selanjutnya tentukan alternatif yang digunakan untuk mendapatkan supplier obat yang terbaik yang terdapat pada Gambar 1.

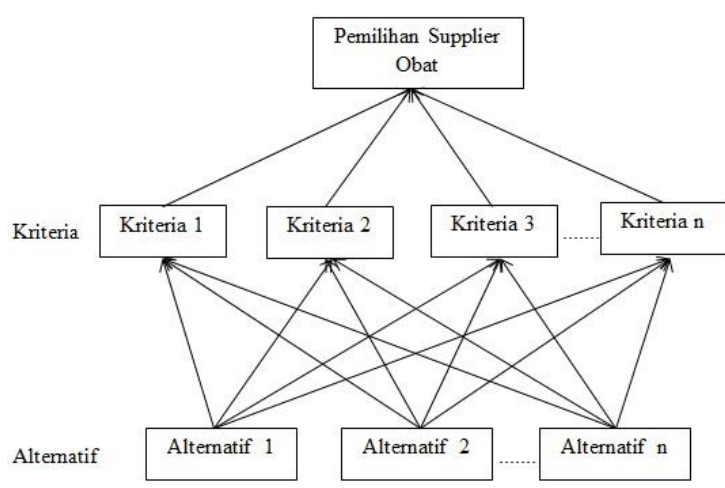

Gambar 1 Struktur Hirarki Alternatif Pemilihan Supplier Obat

Langkah - langkah dari metode SAW, adalah :

a. Menentukan kriteria-kriteria yang akan dijadikan acuan dalam pengambilan keputusan, yaitu $\mathrm{C}$.

b. Menentukan rating kecocokan setiap alternatif pada setiap kriteri

c. Membuat matriks keputusan berdasarkan kriteria (C), 
d. Melakukan normalisasi matriks berdasarkan persamaan yang disesuaikan dengan jenis atribut (atribut keuntungan ataupun atribut biaya) sehingga diperoleh matriks ternormalisasi R.

$$
R i j\left\{\begin{array}{l}
X i j / \operatorname{Max} i j(i) \text { jika j adalah atribut benefit } \\
\text { Min } i j / X i j(i) \text { jika j adalah atribut cost }
\end{array}\right.
$$

$$
\begin{array}{ll}
\text { Dengan: } & \\
R i j & \text { : Nilai rating kinerja ternormalisasi } \\
X i j & \text { : nilai atrinut yang dimiliki dari setiap } \\
& \text { kriteria } \\
\text { Max } X i j & \text { : Nilai terbesar dari setiap kriteria } \\
\text { Min } X i j & \text { : Nilai terkecil dari setiap kriteria } \\
\text { Benefit } & \text { : Jika nilai terbesar adalah terbaik } \\
\text { Cost } & \text { : Jika nilai terkecil adalah terbaik dimana } \\
& \text { rij adalah rating kinerja ternormalisasi } \\
& \text { dari alternatif Ai pada atribut Cj; i } \\
& : 1,2, \ldots, \mathrm{m} \text { dan } \mathrm{j}: 1,2, \ldots, \mathrm{n} .
\end{array}
$$

e. Hasil akhir diperoleh dari proses perankingan yaitu penjumlahan dari perkalian matriks ternormalisasi $\mathrm{R}$ dengan vector bobot sehingga diperoleh nilai terbesar yang dipilih sebagai alternatif terbaik (A) sebagai solusi.

$$
V i=\sum_{j=1}^{n} W j r i j
$$

Dengan:

$V i$ : rangking untuk setiap alternatif

$w j$ : nilai bobot dari setiap kriteria

rij : nilai rating kinerja ternormalisasi

\section{Faktor Pemilihan Supplier}

Pada tahap ini yang akan dilakukan untuk pemilihan supplier terbaik yang memiliki efisiensi dalam memenuhi kebutuhan apotek secara konsisten dan meminimasi resiko yang berkaitan dengan pengadaan obat-obatan maupun komponen yang dibutuhkan apotek, adapun factor yang dijadikan pertimbangan dalam pemilihan supplier terbaik:

a. Kualitas

Kualitas menggambarkan kemampuan suatu produk di apotek dalam memenuhi kebutuhan pelanggan, apakah produk yang ditawarkan supplier dapat disajikan dengan baik ke pelanggan. Kualitas juga bertujuan untuk menjaga reputasi dan konsistensi dalam bekerja sama dengan apotek.

b. Harga

Harga ditetapkan sebagai kriteria karena harga merupakan faktor yang berpengaruh dalam pemilihan supplier, karena harga merupakan hal utama yang menjadi acuan oleh para apotek dalam pemilihan suatu produk.

c. Petunjuk kegunaan

Petunjuk kegunaan dijadikan kriteria karena penjelasan mengenai suatu produk terlebih lagi obat, sangat penting bagi konsumen. Jika petunjuk pengunaan tidak begitu jelas diterangkan maka obat tersebut akan kurang diminati. d. Garansi

Garansi menggambarkan jaminan terhadap suatu produk jika produk tersebut rusak atau tidak sesuai dengan yang diharapkan oleh konsumen.

e. Pengemasan

Pengemasan mencakup rapi atau tidaknya suatu produk oleh supplier saat dikirimkan kepada Apotek. Pengemasan merupakan bentuk fisik yang menjadi pertimbangan dalam pembelian produk.

f. Pemenuhan pesanan

Pemenuhan pesanan menjadi kriteria yang ditetapkan karena merupakan faktor yang cukup penting, apakah pesanan yang diinginkan oleh Apotek dikirimkan sesuai dengan jumlah pesanan yang seharusnya.

g. Pelayanan

Pelayanan menggambarkan seberapa baik pihak supplier dalam melayani kebutuhan Apotek, keramahan dalam melayani juga merupakan salah satu faktor yang cukup penting dalam pemilihan supplier.

Nilai bobot tiap kriteria ditentukan oleh pemilik Apotek Mama Jakarta. Setiap kriteria dapat memiliki nilai bobot yang sama maupun berbeda Untuk melakukan pengambilan keputusan ini terdapat objek yang akan dibahas atau goal dari kriteria yang telah ditentukan.

\section{Hasil dan Pembahasan}

Dari 30 data penilaian supplier obat di apotek, diambil 10 sampel untuk hitung manual. Proses penyelesaian dengan menggunakan metode Simple Additive Weighting, langkah-langkahnya :

1. Analisis Kriteria dan Pembobotan

Pada proses pembuatan sistem pendukung keputusan pemilihan supplier obat di apotek, dibutuhkan pembobotan pada setiap kriteria yang telah ditetapkan sebelumnya. Terdapat 7 (tujuh) kriteria yang akan digunakan yang terdapat pada Tabel 1 .

Tabel 1. Bobot Masing-Masinh Kriteria

\begin{tabular}{|c|c|c|}
\hline No & Kriteria & Bobot \\
\hline 1 & Kualitas & $25 \%$ \\
\hline 2 & Harga & $10 \%$ \\
\hline 3 & Petunjuk kegunaan & $10 \%$ \\
\hline 4 & Garansi & $15 \%$ \\
\hline 5 & Pengemesan & $10 \%$ \\
\hline 6 & Pemenuhan pesanan & $15 \%$ \\
\hline 7 & Pelayanan & $15 \%$ \\
\hline
\end{tabular}

2. Rating Kecocokan

Dalam penentuan rating kecocokan maka nilai dari masing-masing kriteria dimasukkan kedalam tabel rating kecocokan yang telah disesuaikan dengan nilai dari tabel kriteria dengan skla penilaian alternatif yang terdapat pada Tabel 2.

Tabel 2. Skala Penilaian Alternatif 


\begin{tabular}{|c|c|}
\hline Nilai & Skala penilaian \\
\hline 1 & Sangat buruk \\
\hline 2 & Buruk \\
\hline 3 & Cukup \\
\hline 4 & Baik \\
\hline 5 & Sangat baik \\
\hline
\end{tabular}

Dimana data-data yang di inputkan sesuai dengan data yang sebenarnya dan sesuai dengan kriteria yang sudah ditentukan melalui proses perhitungan, terdapat pada Tabel 3 .

Tabel 3 Matrik Keputusan berdasarkan Kriteria

\begin{tabular}{|c|c|c|c|c|c|c|c|}
\hline \multirow{2}{*}{ Alternatif } & \multicolumn{7}{|c|}{ Kriteria } \\
\cline { 2 - 8 } & $\mathrm{C} 1$ & $\mathrm{C} 2$ & $\mathrm{C} 3$ & $\mathrm{C} 4$ & $\mathrm{C} 5$ & $\mathrm{C} 6$ & $\mathrm{C} 7$ \\
\hline $\mathrm{A}_{1}$ & 4 & 4 & 3 & 4 & 4 & 3 & 4 \\
\hline $\mathrm{A}_{2}$ & 5 & 5 & 5 & 4 & 5 & 5 & 5 \\
\hline $\mathrm{A}_{3}$ & 3 & 4 & 3 & 3 & 4 & 4 & 3 \\
\hline $\mathrm{A}_{4}$ & 4 & 3 & 3 & 3 & 4 & 3 & 4 \\
\hline $\mathrm{A}_{5}$ & 4 & 4 & 4 & 4 & 4 & 4 & 3 \\
\hline $\mathrm{A}_{6}$ & 3 & 4 & 3 & 4 & 4 & 4 & 5 \\
\hline $\mathrm{A}_{7}$ & 4 & 4 & 3 & 4 & 4 & 4 & 4 \\
\hline $\mathrm{A}_{8}$ & 4 & 4 & 3 & 3 & 4 & 4 & 4 \\
\hline $\mathrm{A}_{9}$ & 4 & 4 & 4 & 5 & 5 & 5 & 5 \\
\hline $\mathrm{A}_{10}$ & 4 & 4 & 4 & 4 & 4 & 4 & 4 \\
\hline
\end{tabular}

3. Membuat matrik keputusan berdasarkan kriteria

Berdasarkan pada Table 3 diatas, dapat dibentuk matrik keputusan $\mathrm{X}$ dengan data berikut :

$$
\mathrm{X}=\left\{\begin{array}{lllllll}
4 & 4 & 3 & 4 & 4 & 3 & 4 \\
5 & 5 & 5 & 4 & 5 & 5 & 5 \\
3 & 4 & 3 & 3 & 4 & 4 & 3 \\
4 & 3 & 3 & 3 & 4 & 3 & 4 \\
4 & 4 & 4 & 4 & 4 & 4 & 4 \\
3 & 4 & 3 & 4 & 4 & 4 & 5 \\
4 & 4 & 3 & 4 & 4 & 4 & 4 \\
4 & 4 & 3 & 3 & 4 & 4 & 4 \\
4 & 4 & 4 & 5 & 5 & 5 & 5 \\
4 & 4 & 4 & 4 & 4 & 4 & 4
\end{array}\right\}
$$

4. Normalisasi Matrik

$r i j\left\{\begin{array}{l}X i j / \operatorname{Max} i j(i) \text { jika j adalah atribut benefit } \\ \text { Min } i j / X i j(i) \quad \text { jika j adalah atribut cost (1) }\end{array}\right.$
Hasil normalisasi (R) yang di peroleh dari rumus di atas :

$R=\left\{\begin{array}{ccccccc}0,8 & 0,75 & 0,6 & 0,8 & 0,8 & 0,6 & 0,8 \\ 1 & 0,6 & 1 & 0,8 & 1 & 1 & 1 \\ 10,6 & 0,75 & 0,6 & 0,6 & 0,8 & 0,8 & 0,6 \\ 0,8 & 1 & 0,6 & 0,6 & 0,8 & 0,6 & 0,8 \\ 0,8 & 0,75 & 0,8 & 0,8 & 0,8 & 0,8 & 0,6 \\ 0,6 & 0,75 & 0,6 & 0,8 & 0,8 & 0,8 & 1 \\ 0,8 & 0,75 & 0,6 & 0,8 & 0,8 & 0,8 & 0,8 \\ 0,8 & 0,75 & 0,6 & 0,6 & 0,8 & 0,8 & 0,8 \\ 0,8 & 0,75 & 0,8 & 1 & 1 & 1 & 1 \\ 0,8 & 0,75 & 0,8 & 0,8 & 0,8 & 0,8 & 0,8\end{array}\right\}$

\section{Perengkingan}

Tahap terakhir untuk mendapatkan proses perangkingan yaitu penjumlahan dari perkalian matriks ternormalisasi $\mathrm{R}$ dengan vector bobot sehingga diperoleh nilai terbesar yang dipilih sebagai alternatif terbaik (A) sebagai solusi.

$$
V i=\sum_{j=1}^{n} W j r i j
$$

Bobot Kriteria $=[0,25 ; 0,1 ; 0,1 ; 0,15 ; 0,1 ; 0,15$;

$$
0,15]
$$

$$
\begin{array}{ll} 
& =(0,8)(0,25)+(0,75)(0,1)+(0,6)(0,1)+ \\
& (0,8)(0,15)+(0,8)(0,1)+(0,6)(0,15)+ \\
& (0,8)(0,15) \\
& =0,2+0,075+0,06+0,12+0,8+0,09+ \\
& 0,12 \\
& =0,745 \\
\text { V2 } & =(1)(0,25)+(0,6)(0,1)+(1)(0,1)+ \\
& (0,8)(0,15)+(1)(0,1)+(1)(0,15)+(1)(0,15) \\
& =0,25+0,06+0,1+0,12+0,1+0,15+ \\
& 0,15 \\
& =0,93 \\
& =(0,6)(0,25)+(0,75)(0,1)+(0,6)(0,1)+ \\
& (0,6)(0,15)+(0,8)(0,1)+(0,8)(0,15)+ \\
& (0,6)(0,15) \\
& =0,15+0,075+0,06+0,09+0,08+0,12+ \\
& 0,09 \\
& =0,665 \\
& =(0,8)(0,25)+(1)(0,1)+(0,6)(0,1)+ \\
& (0,6)(0,15)+(0,8)(0,1)+(0,6)(0,15)+ \\
& (0,8)(0,15) \\
& =0,2+0,1+0,06+0,09+0,08+0,09+ \\
& 0,12 \\
& =0,74 \\
& =(0,8)(0,25)+(0,75)(0,1)+(0,8)(0,1)+ \\
& (0,8)(0,15)+(0,8)(0,1)+(0,8)(0,15)+ \\
& (0,6)(15) \\
& =0,2+0,075+0,08+0,12+0,08+0,12+ \\
& 0,09 \\
& =0,765
\end{array}
$$




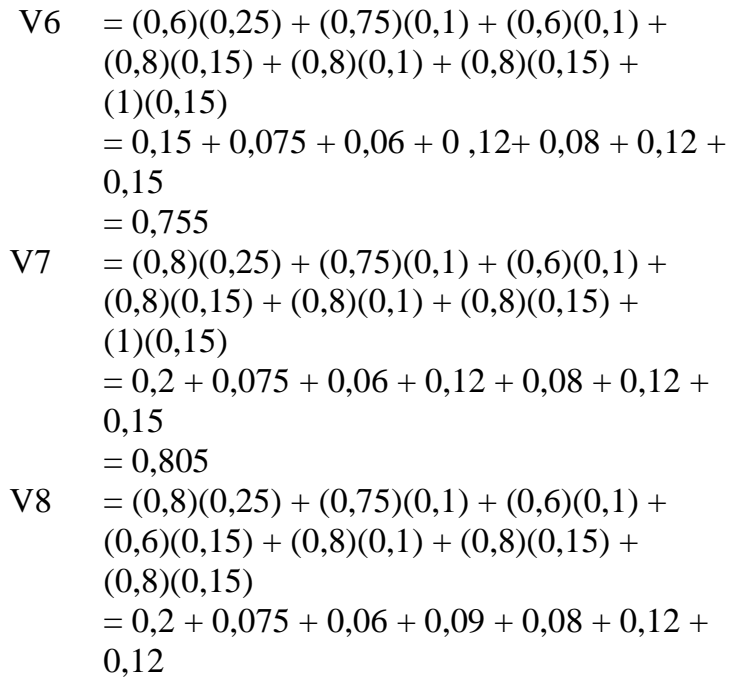

Tabel 4. Hasil Nilai Data Sampel

\begin{tabular}{|c|c|c|c|c|c|c|c|c|c|}
\hline \multirow{2}{*}{ No. } & \multirow{2}{*}{ Alternatif } & \multicolumn{7}{|c|}{ KRITERIA } & \multirow{2}{*}{ Hasil } \\
\cline { 2 - 9 } & & C1 & C2 & C3 & C4 & C5 & C6 & C7 & \\
\hline 1 & A1 & 0,2 & 0,075 & 0,06 & 0,12 & 0,08 & 0,09 & 0,12 & 0,745 \\
\hline 2 & A2 & 0,25 & 0,06 & 0,1 & 0,12 & 0,1 & 0,15 & 0,15 & 0,93 \\
\hline 3 & A3 & 0,15 & 0,075 & 0,06 & 0,09 & 0,08 & 0,12 & 0,09 & 0,665 \\
\hline 4 & A4 & 0,2 & 0,1 & 0,06 & 0,09 & 0,08 & 0,09 & 0,12 & 0,74 \\
\hline 5 & A5 & 0,2 & 0,075 & 0,08 & 0,12 & 0,08 & 0,12 & 0,09 & 0,765 \\
\hline 6 & A6 & 0,15 & 0,075 & 0,06 & 0,12 & 0,08 & 0,12 & 0,15 & 0,755 \\
\hline 7 & A7 & 0,2 & 0,075 & 0,06 & 0,12 & 0,08 & 0,12 & 0,15 & 0,805 \\
\hline 8 & A8 & 0,2 & 0,075 & 0,06 & 0,09 & 0,08 & 0,12 & 0,12 & 0,745 \\
\hline 9 & A9 & 0,2 & 0,075 & 0,08 & 0,15 & 0,1 & 0,15 & 0,15 & 0,905 \\
\hline 10 & A10 & 0,2 & 0,075 & 0,08 & 0,12 & 0,08 & 0,12 & 0,12 & 0,795 \\
\hline
\end{tabular}

6. Hasil Keputusan Perengking Supplier Obat Apotek Mama Jakarta

Hasil pengelompokan di atas belum mendapatkan hasil yang sebenarnya untuk ke 10 sampel supplier obat, sehingga perlu dilakukan mengurutkan nilai hasil tertinggi sampai kehasil terendah. Hasil perengkingan dari ke 10 sampel supplier obat dapat dilihat pada Tabel 5.

Tabel 5. Hasil Perengkingan (P) Supplier Obat Apotek Mama Jakarta

\begin{tabular}{|c|c|c|c|c|c|c|c|c|c|c|}
\hline \multirow{2}{*}{ No. } & \multirow{2}{*}{ Alternatif } & \multicolumn{7}{|c|}{ KRITERIA } & \multirow{2}{*}{ Hasil } & \multirow{2}{*}{ P } \\
\cline { 3 - 11 } & & C1 & C2 & C3 & C4 & C5 & C6 & C7 & & \\
\hline 1 & A2 & 0,25 & 0,06 & 0,1 & 0,12 & 0,1 & 0,15 & 0,15 & 0,93 & 1 \\
\hline 2 & A9 & 0,2 & 0,075 & 0,08 & 0,15 & 0,1 & 0,15 & 0,15 & 0,905 & 2 \\
\hline 3 & A7 & 0,2 & 0,075 & 0,06 & 0,12 & 0,08 & 0,12 & 0,15 & 0,805 & 3 \\
\hline 4 & A10 & 0,2 & 0,075 & 0,08 & 0,12 & 0,08 & 0,12 & 0,12 & 0,795 & 4 \\
\hline 5 & A5 & 0,2 & 0,075 & 0,08 & 0,12 & 0,08 & 0,12 & 0,09 & 0,765 & 5 \\
\hline 6 & A6 & 0,15 & 0,075 & 0,06 & 0,12 & 0,08 & 0,12 & 0,15 & 0,755 & 6 \\
\hline
\end{tabular}




\begin{tabular}{|c|c|c|c|c|c|c|c|c|c|c|}
7 & A1 & 0,2 & 0,075 & 0,06 & 0,12 & 0,08 & 0,09 & 0,12 & 0,745 & 7 \\
\hline 8 & A8 & 0,2 & 0,075 & 0,06 & 0,09 & 0,08 & 0,12 & 0,12 & 0,745 & 8 \\
\hline 9 & A4 & 0,2 & 0,1 & 0,06 & 0,09 & 0,08 & 0,09 & 0,12 & 0,74 & 9 \\
\hline 10 & A3 & 0,15 & 0,075 & 0,06 & 0,09 & 0,08 & 0,12 & 0,09 & 0,665 & 10 \\
\hline
\end{tabular}

Dari Tabel 5. maka didapatkan keputusan perengkingan dari 10 sample supplier obat, dimana yang mendapatkan peringkat ke 1 adalah A2 dengan hasil yang diperoleh 0,93. keputusan promosi Kenaikan jabatan, Jurnal Pilar Nusa Mandiri Vol.XII, No. 1 Maret 2016, ISSN 1978-1946

\section{Kesimpulan}

Kesimpulan yang didapatkan dari hasil penelitian yang telah dilakukan. Penerapan metode Simple Additive Weighting (SAW) dapat membantu dalam pengambilan keputusan yang optimal dalam pemilihan supplier, serta di implementasikan dengan mudah dan memberikan rekomendasi supplier yang terbaik sesuai dengan kriteria yang ditentukan pada proses peemilihan supplier.

\section{Daftar Pustaka}

[1] Pradiptaa Aldi Yudha dan Diana Anita, 2017. Sistem Penunjang Keputusan Pemilihan Supplier pada Apotek dengan Metode AHP dan SAW (Studi Kasus Apotek XYZ), PROSIDING seminar nasional sisfotek Sistem Informasi dan Teknologi Informasi, ISSN 2597-3584 (media online)

[2] Ningsih Rahayu, 2016. Penentuan Pemilihan Supplier Bahan Baku Oli Bs150 Menggunakan Analytical Hierarchy Process, Jurnal Teknik Komputer AMIK BSI, Vol.Ii, No.2, ISSN 2442-2436

[3] Melia Yeni, 2016. Multi Attribute Decision Making Using Simple Additive Weighting and Weighted Product in Investment, International Conference on Electrical Engineering and Informatics, Vol. 3, No. 7, ISSN 2454-2768

[4] Dogan Mahmut, Aktar Tuğba, Said Toker Omer dan Berna Tatlisu Nevruz, 2015. Combination of the Simple Additive (SAW) Approach and Mixture Design to Determine Optimum Cocoa Combination of the Hot Chocolate Beverage, ISSN: 1094-2912 (Print) 1532-2386 (Online) Journal homepage: http://www.tandfonline.com/loi/ljfp20

[5] Irvanizam Irvanizam, 2017. Multiple Attribute Decision Making with Simple Additive Weighting Approach for Selecting the Scholarship Recipients at Syiah Kuala University, nternational Conference on Electrical Engineering and Informatics, DOI: 10.1109/ICELTICS.2017.8253272

[6] Frieyadie, 2016. Penerapan metode simple additive weight (saw) Dalam sistem pendukung
[7] Ivanjelita Lia Ayu, Utami Ema dan Luthfi Emha Taufiq, 2015. Sistem Pendukung Keputusan Seleksi Penerimaan Calon Asisten Praktikum, Jurnal Ilmiah DASI Vol. 16 No. 4 Desember 2015, hlm 37 - 46 ISSN: 1411-3201

[8] Guswandi Dodi, 2017. Sistem Pendukung Keputusan Bantuan Bedah Rumah Menggunakan Metode Simple Additive Weighting Pada Badan Amil Zakat, Majalah Ilmiah, Vol. 24, No. 1, April 2017, Hal. 221234 E-ISSN 2502-8774 P-ISSN 1412-5854

[9] Sujarwadi Asep dan Abidin Dodo Zaenal, 2016. Perancangan Sistem Pendukung Keputusan Dengan Metode Simple Additive Weighting (SAW) Dalam Penentuan Tunjangan Kinerja Pegawai Pada Kepolisian Resort Kota (Polresta) Jambi, Jurnal Manajemen Sistem Informasi Vol 1 No. 1, September 2016 ISSN : 2540-8011

[10] Wahyuni Elyza Gustri dan Anggoro Ananto Tri, 2017. Sistem Pendukung Keputusan Penerimaan Pegawai dengan Metode TOPSIS, Jurnal Sains, Teknologi dan Industri, Vol. 14, No. 2, Juni 2017, pp.108 - 116, ISSN 16932390 print/ISSN 2407-0939 online

[11] Ningsih Rahayu, 2016. Penentuan Pemilihan Supplier Bahan Baku Oli Bs150 Menggunakan Analytical Hierarchy Process, Jurnal Teknik Komputer AMIK BSI, Vol.Ii, No.2, ISSN 2442-2436

[12] Fitriyani, 2016. Sistem Pendukung Keputusan Pemilihan Mahasiswa Berprestasi di STMIK Atma Luhur Pangkalpinang dengan Menggunakan Metode Analytical Hierarchy Process (AHP), TEKNOSI, Vol. 02, No. 02, ISSN $2476-8812$

[13] Tammasarangoon Orasa dan Thiengburanathum Poon, 2016. Study And Implement Delivery Method For Decision Support Systems Of Chiang Mai Urban Transit, International Conference on Software, Knowledge, Information Management \& Applications (SKIMA), DOI: 10.1109/SKIMA.2016.7916244 